\title{
Enhanced CXCL12/CXCR4 signaling increases tumor progression in radiation-resistant pancreatic cancer
}

\author{
TOMOKATSU KATO, YOICHI MATSUO, GORO UEDA, HIROMICHI MURASE, \\ YOSHINAGA AOYAMA, KAN OMI, YUICHI HAYASHI, HIROYUKI IMAFUJI, KENTA SAITO, \\ MAMORU MORIMOTO, RYO OGAWA, HIROKI TAKAHASHI and SHUJI TAKIGUCHI \\ Department of Gastroenterological Surgery, Nagoya City University Graduate School of Medical Sciences, \\ Nagoya, Aichi 467-8601, Japan
}

Received October 21, 2021; Accepted January 20, 2022

DOI: $10.3892 /$ or.2022.8279

\begin{abstract}
Pancreatic cancer ( $\mathrm{PaCa}$ ) exhibits one of the poorest prognoses among all gastrointestinal cancers due to the rapid development of treatment resistance, which renders chemotherapy and radiotherapy no longer effective. However, the mechanisms through which $\mathrm{PaCa}$ becomes resistant to radiotherapy are unknown. Here, we established radiation-resistant $\mathrm{PaCa}$ cell lines to investigate the factors involved in radiation resistance. The role of the $\mathrm{C}-\mathrm{X}-\mathrm{C}$ motif chemokine ligand 12 (CXCL12)/C-X-C chemokine receptor type 4 (CXCR4) axis in radiation resistance in $\mathrm{PaCa}$ and the effects of a CXCR4 antagonist on radiation-resistant $\mathrm{PaCa}$ cell lines were investigated. As confirmed by immunofluorescence staining, reverse transcription quantitative polymerase chain reaction, and western blotting, the expression of CXCR4 was higher in radiation-resistant $\mathrm{PaCa}$ cell lines than that noted in normal $\mathrm{PaCa}$ cell lines. The invasion ability of radiation-resistant $\mathrm{PaCa}$ cell lines was greater than that of normal cell lines and was enhanced by CXCL12 treatment and coculture with fibroblasts; this enhanced invasion ability was suppressed by the CXCR4 antagonist AMD070. Irradiation after treatment with the CXCR4 antagonist suppressed the colonization of radiation-resistant $\mathrm{PaCa}$ cell lines. In conclusion, the CXCL12/CXCR4 axis may be involved in the
\end{abstract}

Correspondence to: Professor Yoichi Matsuo, Department of Gastroenterological Surgery, Nagoya City University Graduate School of Medical Sciences, 1 Kawasumi, Mizuho-cho, Mizuhoku, Nagoya, Aichi 467-8601, Japan

E-mail: matsuo@med.nagoya-cu.ac.jp

Abbreviations: $\mathrm{PaCa}$, pancreatic cancer; CXCR4, C-X-C chemokine receptor type 4; CXCL12, C-X-C motif chemokine ligand 12; HPDE, human pancreatic duct epithelial; FB, fibroblast; RT-qPCR, reverse-transcription quantitative PCR; CAFs, cancerassociated fibroblasts; CXCR7, C-X-C chemokine receptor type 7

Key words: pancreatic cancer, radiation-resistant, CXCR4, CXCL12, CXCR4 antagonist radiation resistance of $\mathrm{PaCa}$. These findings may facilitate the development of novel treatments for $\mathrm{PaCa}$.

\section{Introduction}

Pancreatic cancer $(\mathrm{PaCa})$ has one of the poorest prognoses among all gastrointestinal cancers and is the third leading cause of cancer-related death in the US (1). In recent years, new chemotherapy regimens, such as FOLFIRINOX and nab-paclitaxel plus gemcitabine, and new radiotherapy modalities, such as stereotactic body radiotherapy, intensity modulated radiotherapy, and carbon-ion radiotherapy, have been introduced (2-6). However, the 5-year survival rate of patients with $\mathrm{PaCa}$ is still very low, at $8.5-9 \%(1,7)$. Because the number of patients with $\mathrm{PaCa}$ is expected to increase (8), there is an urgent need to develop new treatment methods.

One of the main reasons for the increase in PaCa malignancy is its high local invasion capacity. The most effective treatment for $\mathrm{PaCa}$ is curative surgery $(9,10)$, yet many $\mathrm{PaCa}$ cases are judged unresectable at diagnosis (11). The combination of chemotherapy and radiotherapy for treating locally advanced $\mathrm{PaCa}$ has been reported to prolong overall survival (12); however, these approaches are often not sufficiently effective because PaCa quickly becomes resistant to these treatments. The mechanism through which $\mathrm{PaCa}$ develops resistance to radiotherapy remains unclear. Therefore, elucidation of the mechanisms of radiation resistance may improve $\mathrm{PaCa}$ treatment.

Chemokines and their receptors have been discovered as essential and selective mediators in leukocyte migration to the inflammatory site and to secondary lymphoid organs (13). They play critical roles in tumor initiation, promotion, and progression (14). C-X-C chemokine receptor type 4 (CXCR4) is the receptor for $\mathrm{C}-\mathrm{X}-\mathrm{C}$ motif chemokine ligand 12 (CXCL12) and has been shown to act as a coreceptor for human immunodeficiency virus (HIV) entry (15). Recently, the association between CXCR4 and cancer has become a focus of research as CXCR4 is overexpressed in various types of cancer and contributes to tumor growth, angiogenesis, metastasis, and treatment resistance (16-18). Similar results have been described in PaCa (19-22). CXCR4 antagonists were initially developed as a novel treatment for HIV infection $(23,24)$. 
As our understanding of the functions of CXCR4 grows, CXCR4 antagonists are being used for purposes other than anti-HIV treatment. Several reports have described the effects of CXCR4 antagonists on malignant tumors, including breast cancer (25), small cell lung cancer (26), cholangiocarcinoma (27), gastric cancer (28), and $\mathrm{PaCa}$ (29-31). We previously reported that the CXCL12/CXCR4 axis is involved in gemcitabine resistance in $\mathrm{PaCa}$ and that a CXCR4 antagonist exhibits antitumor effects on gemcitabine-resistant $\mathrm{PaCa}$ cell lines (32). However, the role of CXCR4 in PaCa radiation resistance is still unknown.

Here, we established two radiation-resistant PaCa cell lines. Using multiple methods, we confirmed the higher expression of CXCR4 in radiation-resistant cells compared with that in normal $\mathrm{PaCa}$ cell lines. The purpose of this study was to clarify the roles of the CXCL12/CXCR4 axis in radiation resistance in $\mathrm{PaCa}$ and evaluate the effects of CXCR4 antagonism on radiation-resistant $\mathrm{PaCa}$ cell lines.

\section{Materials and methods}

Reagents. AMD070 trihydrochloride $\left(\mathrm{C}_{21} \mathrm{H}_{30} \mathrm{Cl}_{3} \mathrm{~N}_{5}\right.$; CID 11256587) was purchased from Med Chem Express (Cosmo Bio Co., Ltd.), and dimethyl sulfoxide (DMSO) was obtained from Sigma-Aldrich (Merck KGaA). AMD070 solution (326.90 $\mathrm{mM}$ ) was prepared in DMSO, stored in small aliquots at $-20^{\circ} \mathrm{C}$, and then thawed and diluted in cell culture medium as required. CXCL12 was purchased from R\&D Systems.

Cell lines and treatments. The human pancreatic duct epithelial (HPDE) cell line H6c7 was purchased from Kerafast. Human skin fibroblasts (FBs; cat. no. T0904) were purchased from Applied Biological Materials. The human PaCa cell lines AsPC-1, BxPC-3, Capan2, MIA PaCa-2, PANC-1, and SW1990 were purchased from the American Type Culture Collection (ATCC). The H6c7 cell line was maintained in keratinocyte serum-free medium (Gibco/Thermo Fisher Scientific, Inc.). The AsPC-1, BxPC-3, and Capan 2 cell lines were maintained in RPMI-1640 medium (Sigma Aldrich; Merck KGaA). The MIA PaCa-2, PANC-1, and SW1990 cell lines and FBs were maintained in Dulbecco's modified Eagle's medium (DMEM; Sigma Aldrich; Merck KGaA). Both RPMI-1640 medium and DMEM were supplemented with $10 \%$ fetal bovine serum (FBS; Gibco/Thermo Fisher Scientific, Inc.). All media were supplemented with $10 \mathrm{mg} / \mathrm{ml}$ streptomycin, 10,000 U/ml penicillin, and $25 \mu \mathrm{g}$ amphotericin B (Gibco/Thermo Fisher Scientific, Inc.). All cell lines were cultured at $37^{\circ} \mathrm{C}$ in a humidified incubator with $5 \% \mathrm{CO}_{2}$.

Establishment of radiation-resistant PaCa cell lines. Radiation-resistant cancer cell lines have been previously established from nasopharyngeal, esophageal, breast, and lung cancers (33-37). Here, we established radiation-resistant $\mathrm{PaCa}$ cell lines by referencing these methods. PaCa cell lines (AsPC-1, BxPC-3, MIA PaCa-2, and SW1990) were seeded in $100-\mathrm{mm}$ dishes and cultured. Upon reaching 50\% confluence, the cells were irradiated with 2 Gy radiation and incubated until reaching $90 \%$ confluence, after which the cells were passaged. With each passage, the irradiation process was repeated until the total radiation dose reached at least $60 \mathrm{~Gy}$. The radiation resistance of the cell lines was assessed by colony formation assay.

Total mRNA microarray analysis. Total mRNA from normal and radiation-resistant MIA $\mathrm{PaCa}-2$ cells was isolated using the RNeasy Plus Mini kit (Qiagen, Inc.) according to the manufacturer's instructions. The mRNA microarray experiments were performed by Hokkaido System Science Co., Ltd. Transcripts amplified from total mRNA were hybridized to a SurePrint G3 Human 8x60K v3 array (Agilent Technologies, Inc.) according to the manufacturer's protocol. The results were analyzed using Agilent Genomic Workbench Software (Agilent Technologies, Inc.).

Colony formation assay. Irradiating a small number of cells with a high radiation dose will kill all cells. Therefore, the number of radiation-resistant $\mathrm{PaCa}$ cells to be seeded (200, $400,1,000,2,000$, or 40,000$)$ depended on the dose $(0,2,4$, 6 , or $10 \mathrm{~Gy}$ ). The cells were seeded in $60-\mathrm{mm}$ dishes, cultured overnight, irradiated with each radiation dose, and cultured at $37^{\circ} \mathrm{C}$ for 14 days. To assess the efficacy of AMD070, a CXCR4 antagonist, $\mathrm{PaCa}$ cells were seeded in 60-mm dishes and treated with $2.5 \mu \mathrm{M}$ AMD070 for $72 \mathrm{~h}$. The treated cells were seeded in $60-\mathrm{mm}$ dishes, cultured overnight, irradiated with 2 Gy radiation, and cultured at $37^{\circ} \mathrm{C}$ for 14 days. Cells were fixed and stained using a Diff-Quick cell staining kit (Dade Behring), and colonies were counted under five different fields. A colony was defined as a group of at least 50 cells.

Immunohistochemistry. Pancreatic tissues were analyzed from 92 patients who underwent surgery at Nagoya City University Hospital (Nagoya, Japan) between January 2006 and December 2016. The mean age of the patients was 67.6 years (range 32-85 years), and the male-female ratio was 62 males and 30 females. All pancreatic tissues were obtained from patients or their relatives who provided informed consent. This study was conducted upon the approval of the institutional review board established by Nagoya City University (approval no. 60-18-0025, date of approval; May 6, 2018).

Specimens were fixed in $10 \%$ formalin and then embedded in paraffin. Specimens were sectioned into 3- $\mu \mathrm{m}$-thick slices, and the sections were deparaffinized, subjected to autoclave treatment in $10 \mathrm{mM}$ sodium citrate buffer for $10 \mathrm{~min}$ at $120^{\circ} \mathrm{C}$, and cooled to room temperature. Next, the sections were treated with $0.3 \% \mathrm{H}_{2} \mathrm{O}_{2}$ in methanol for $30 \mathrm{~min}$, blocked with Block Ace (Megmilk Snow Brand; KAC Co., Ltd.) for $10 \mathrm{~min}$, and incubated with anti-CXCR4 antibody (1:250; Proteintech Group; cat. no. 60042-1-Ig) overnight at $4^{\circ} \mathrm{C}$, followed by EnVision+ System- HRP Labelled Polymer anti-mouse (DAKO/Agilent Technologies; cat. no. K4001) for $45 \mathrm{~min}$ at room temperature. The peroxidase reaction was visualized by incubating the sections with the Liquid DAB+ Substrate Chromogen System (DAKO/Agilent Technologies; cat. no. K3467), followed by hematoxylin counterstaining. Immunohistochemical staining was evaluated as follows. The intensity of CXCR4 immunostaining was graded semi-quantitatively on a 4 -point scale $(-,+,++,+++)$ by three independent observers. Of the 92 patients, 8 had stage 1 disease, 4 had stage 2 disease, 37 had stage 3 disease, 41 had stage 4 disease, and 2 had an unknown disease stage. However, analyses were 
performed in a blinded manner, and the observer was not aware of the patient's stage and outcome. The concordance rate was greater than $90 \%$. Differences in opinion were resolved by consensus with a fourth evaluator. The cases were classified into a high expression group and a weak expression group according to the intensity of immunostaining in cancer cells, in which an immunostaining score of ++ or +++ was defined as high expression.

Immunofluorescence staining. PaCa cells $\left(5 \times 10^{4}\right)$ were seeded in glass chamber slides and cultured overnight. The cells were fixed using $4 \%$ paraformaldehyde for $20 \mathrm{~min}$ at room temperature. Next, the cells were permeabilized with $0.1 \%$ Triton-X for $3 \mathrm{~min}$ and incubated with blocking buffer [3\% bovine serum albumin in phosphate-buffered saline (FUJIFULM Wako Pure Chemical Corp.)] for $1 \mathrm{~h}$ at room temperature. The cells were incubated with anti-CXCR4 antibody (1:200; Abcam; cat. no. ab124824) overnight at $4^{\circ} \mathrm{C}$, followed by Alexa Fluor 488 goat anti-rabbit IgG secondary antibody (1:1,000; Abcam; cat. no. ab6939) for $1 \mathrm{~h}$ at room temperature. The nuclei were visualized by DAPI staining at room temperature for $10 \mathrm{~min}$. Images of the stained slides were captured using a BZ-X710 fluorescence microscope (Keyence Corporation) at x200 magnification.

Reverse-transcription quantitative polymerase chain reaction $(R T-q P C R)$. Total RNA was isolated from HPDE and $\mathrm{PaCa}$ cells using an RNeasy Plus Mini kit (Qiagen $\mathrm{GmbH}$ ), according to the manufacturer's protocols, and quantified using a NanoDrop 1000 (Thermo Fisher Scientific, Inc.). Total RNA $(1 \mu \mathrm{g})$ was reverse transcribed using Super Script III First-Strand Synthesis Super Mix for RT-qPCR (Invitrogen/Thermo Fisher Scientific, Inc.) following the manufacturer's protocols. RT-qPCR was performed using TaqMan Fast Advanced Master Mix and TaqMan Gene Expression Assays for CXCR4 (Hs00607978_s1) and glyceraldehyde 3-phosphate dehydrogenase (GAPDH; Hs99999905_m1) on a 7900HT Fast Real-Time PCR System (all from Applied Biosystems/Thermo Fisher Scientific, Inc.). The following thermocycling conditions were used: initial denaturation at $95^{\circ} \mathrm{C}$ for $20 \mathrm{sec}$, followed by 40 cycles at $95^{\circ} \mathrm{C}$ for $1 \mathrm{sec}$ and $60^{\circ} \mathrm{C}$ for $20 \mathrm{sec}$. The expression level of $C X C R 4$ was reported relative to that of $G A P D H$ in each sample, using the relative standard curve method (38).

Western blotting. Proteins were extracted from cells using radioimmunoprecipitation lysis buffer containing Protease Inhibitor Single Use Cocktail and Phosphatase Inhibitor Cocktail (Thermo Fisher Scientific, Inc.). The protein concentrations were measured using a Pierce BCA protein assay kit (Thermo Fisher Scientific, Inc.). Protein extracts $\left(20\right.$ or $30 \mu \mathrm{g}$ ) were denatured at $90^{\circ} \mathrm{C}$ for $5 \mathrm{~min}$ and separated on $10 \%$ Mini-PROTEAN TGX Precast gels (Bio-Rad Laboratories). The protein bands were transferred to nitrocellulose membranes and blocked in iBind Flex Solution (iBind Flex Buffer, iBind Flex Additive, and distilled water; Thermo Fisher Scientific, Inc.) for $20 \mathrm{~min}$ at room temperature. The primary and secondary antibody reactions were performed for $3 \mathrm{~h}$ at room temperature using the iBind Flex Western System (Thermo Fisher Scientific, Inc.) according to the manufacturer's instructions. The membranes were incubated with
anti-CXCR4 (1:1,000; Proteintech Group; cat. no. 60042-1-Ig) or anti-GAPDH (1:1,000; Santa Cruz Biotechnology; cat. no. SC-47724) primary antibodies, followed by horseradish peroxidase-conjugated goat anti-mouse polyclonal secondary antibodies (1:2,000; DAKO/Agilent Technologies; cat. no. P0447). The protein-antibody complexes were visualized using SuperSignal West Femto Chemiluminescent Substrate or Pierce ECL Western Blotting Substrate (Thermo Fisher Scientific, Inc.). The immunoreactive protein bands were detected using an Amersham Imager 600 (Cytiva), and the densities of the detected bands were calculated using ImageJ software $1.52 \mathrm{v}$ (National Institutes of Health).

RNA interference. CXCR4 small interfering RNA (siRNA; s15412: CCUGUUUCCGUGAAGAAAA) and nontargeting negative control siRNA (Silencer Select Negative Control No. 1; cat. no. 4390843: sequence not provided) were predesigned siRNAs purchased from Thermo Fisher Scientific, Inc. $\mathrm{PaCa}$ cells were seeded at $2.5 \times 10^{5}$ cells/well in 6-well plates, cultured overnight, and then transfected with siRNA. According to the manufacturer's instructions, siRNAs and Lipofectamine RNAiMAX (Invitrogen/Thermo Fisher Scientific, Inc.) were mixed with Opti-MEM (Invitrogen/Thermo Fisher Scientific, Inc.) and incubated for $5 \mathrm{~min}$ at room temperature. The siRNA-lipid complex was diluted in DMEM to achieve a final siRNA concentration of $10 \mathrm{nM}$. Cells were incubated for $48 \mathrm{~h}$ in a $5 \% \mathrm{CO}_{2}$ incubator at $37^{\circ} \mathrm{C}$.

Invasion assay. In vitro invasion assays were performed using Corning BioCoat Matrigel Invasion Chambers (Corning, Inc.) according to the manufacturer's protocol. Normal and radiation-resistant $\mathrm{PaCa}$ cells $\left(1 \times 10^{5}\right)$ were seeded in the upper chamber, which contained DMEM without FBS. The chemoattractant used in the lower chamber was $10 \%$ FBS in DMEM. In addition, AMD070 $(1 \mu \mathrm{M})$ and CXCL12 (100 ng/ml) were added to the lower chamber, or the cells were cocultured with FBs. After incubation for $24 \mathrm{~h}$, the upper surface of the upper chambers was wiped with a cotton swab, and the invading cells were fixed and stained using a Diff-Quick cell staining kit (Dade Behring). The number of cells in nine random microscopic fields (x200 magnification) was counted.

Statistical analysis. Differences between two samples were analyzed using unpaired t-tests. Multiple group comparisons were performed by one-way analysis of variance with the post-hoc Bonferroni test for subsequent comparisons of individual groups. Comparisons of groups with two independent variables were performed using two-way analysis of variance. Comparisons of patient stage were performed using Fisher's exact test. Survival curves based on CXCR4 expression were generated using the Kaplan-Meier method and were compared using log-rank tests. Results with a P-value $<0.05$ were considered statistically significant. The data from experiments performed in at least triplicate are expressed as means \pm standard deviations.

\section{Results}

Association between CXCR4 expression in PaCa tissues and patient survival. Resected tissue specimens from 
patients with $\mathrm{PaCa}$ were subjected to CXCR4 immunostaining (Fig. 1A). The patients were divided into low and high CXCR4 expression groups according to the intensity of CXCR4 immunostaining, and survival curves were generated. Of the 29 patients in the high expression group, 2 had stage 1 disease, none had stage 2 disease, 9 had stage 3 disease, 17 had stage 4 disease, and 1 had an unknown disease stage. Of the 63 patients in the low expression group, 6 had stage 1 disease, 4 had stage 2 disease, 28 had stage 3 disease, 24 had stage 4 disease, and 1 had an unknown disease stage. There were no differences in staging between the high and low expression groups $(\mathrm{P}=0.233)$. Overall survival $(\mathrm{OS})$ was significantly worse in the high expression group ( $\mathrm{P}=0.0068$; Fig. 1B).

Enhanced expression of CXCR4 in PaCa cells, but not HPDE cells. Expression of CXCR4 in H6c7 HPDE cells, which are derived from the near normal pancreatic duct epithelium, and in PaCa cell lines (AsPC-1, BxPC-3, Capan2, MIA PaCa-2, PANC-1, and SW1990) was evaluated by RT-qPCR and western blotting. Both CXCR4 mRNA (Fig. 2A) and protein (Fig. 2B and 2C) levels were significantly higher in PaCa cell lines than in HPDE cells $(\mathrm{P}<0.05)$.

Establishment of radiation-resistant PaCa cell lines. We succeeded in establishing radiation resistance in two PaCa cell lines, MIA PaCa-2 and SW1990. MIA PaCa-2 and SW1990 cells were irradiated with 120 and $60 \mathrm{~Gy}$, respectively. The decrease in colonization after exposure to high doses of radiation was significantly attenuated in the radiation-resistant cells compared with that in their normal counterparts $(\mathrm{P}<0.05$; Fig. 3A-D).

cDNA microarray analysis of normal and radiation-resistant MIA PaCa-2 cells. To investigate comprehensive differences in cDNA expression between normal and radiation-resistant MIA PaCa-2 cells, we used a cDNA microarray containing 62,976 probe sets. Of these probes, 2,397 had higher expression (cut-off value, 2-fold) and 2,154 had lower expression (cut-off value, 0.5 -fold) in radiation-resistant cells compared with that in normal MIA PaCa-2 cells. Among stem cell markers of $\mathrm{PaCa}$ and chemokine receptors, CXCR4 showed the highest expression level (Table I).

Enhanced expression of $\mathrm{CXCR} 4$ in radiation-resistant $\mathrm{PaCa}$ cell lines. Immunofluorescence staining of CXCR4 in normal and radiation-resistant $\mathrm{PaCa}$ cell lines confirmed the higher expression of CXCR4 in radiation-resistant $\mathrm{PaCa}$ cell lines (Fig. 4A). RT-qPCR and western blotting further confirmed that CXCR4 mRNA (Fig. 4B) and protein (Fig. 4C-F) levels were significantly increased in radiation-resistant $\mathrm{PaCa}$ cell lines compared with those in normal $\mathrm{PaCa}$ cell lines $(\mathrm{P}<0.05)$.

Changes in CXCR4 expression level after knockdown of CXCR4 in PaCa cell lines. RT-qPCR was performed to evaluate changes in the expression of CXCR4 mRNA in $\mathrm{PaCa}$ cell lines transfected with $C X C R 4$ siRNA. Transfection with CXCR4 siRNA significantly downregulated CXCR4 in $\mathrm{PaCa}$ cell lines compared with that in control cells and cells transfected with negative control siRNA ( $\mathrm{P}<0.05$; Fig. S1).
A
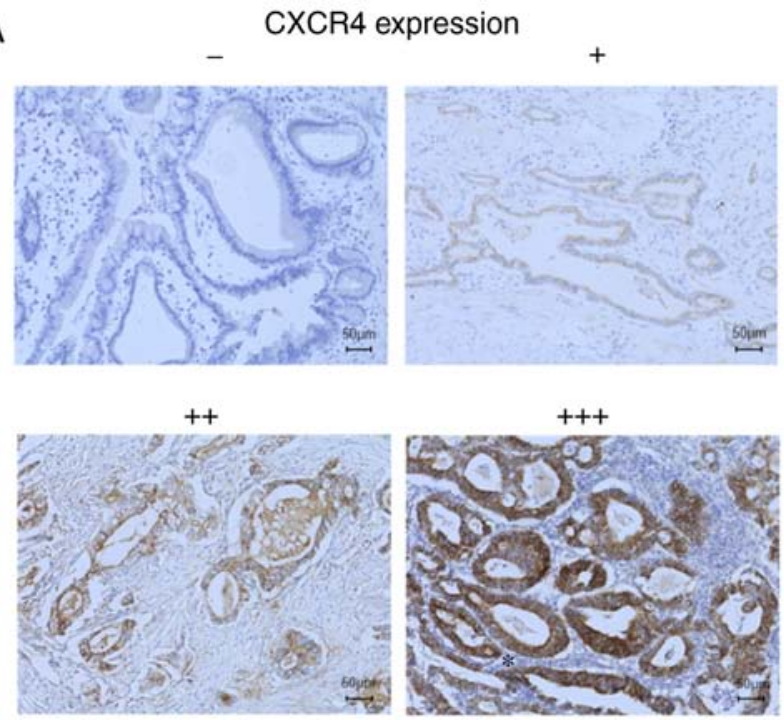

B

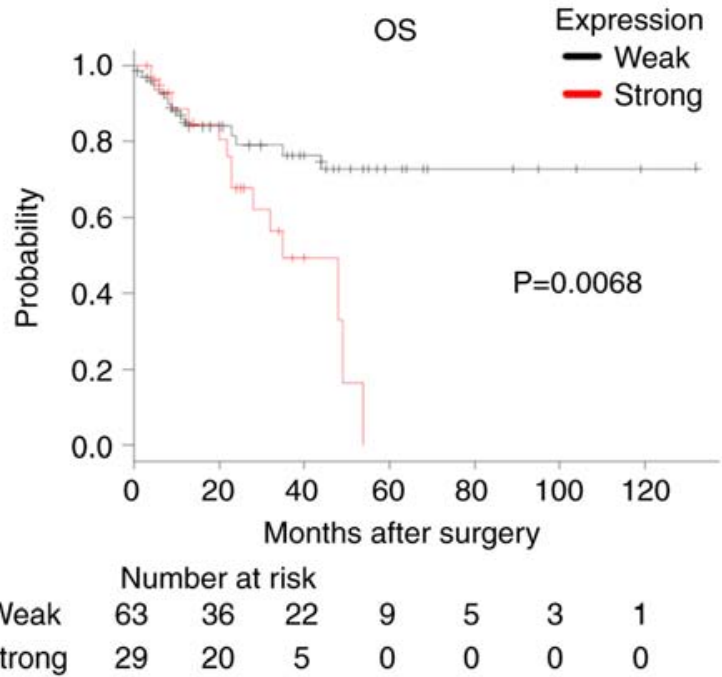

Figure 1. C-X-C chemokine receptor type 4 (CXCR4) expression in pancreatic tissue. (A) Immunohistochemical expression of CXCR4 in pancreatic tissue specimens, performed using a monoclonal anti-CXCR4 antibody. Magnification, x200. The intensity of CXCR4 immunostaining was graded semi-quantitatively on a four-point scale $(-,+,++,+++)$ by three independent observers who were blinded to the disease stage and patient outcome. (B) Kaplan-Meier survival curves of patients with pancreatic cancer. The survival curves of patients with weak vs. strong CXCR4 expression were compared. OS, overall survival.

The role of the CXCL12/CXCR4 axis in PaCa cell invasion and the effects of CXCR4 knockdown on cell invasion. There were no significant differences in cell invasion ability between the negative control group and the CXCR4-knockdown group. Addition of CXCL12 enhanced the invasion ability of PaCa cell lines, and this effect was suppressed by CXCR4 knockdown (Fig. S2).

Role of the CXCL12/CXCR4 axis in PaCa cell invasion and the effects of AMD070 on cell invasion. Cell invasion ability was greater in radiation-resistant $\mathrm{PaCa}$ cell lines (MIA PaCa-2 and SW1990) than in normal PaCa cell lines. The addition of CXCL12 enhanced the invasion ability of $\mathrm{PaCa}$ cell lines, and this effect was suppressed by AMD070 


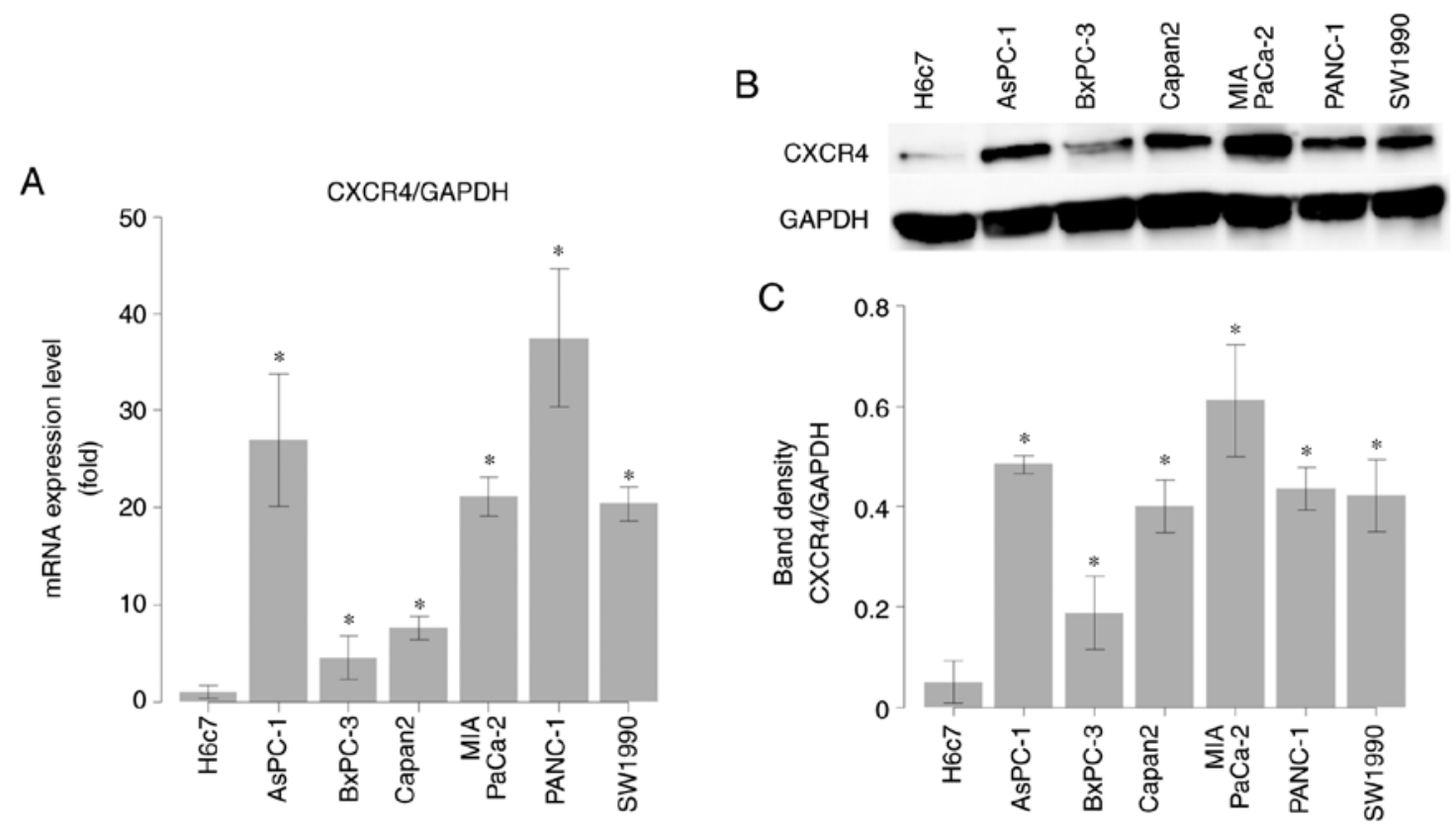

Figure 2. Comparison of C-X-C chemokine receptor type 4 (CXCR4) expression between human pancreatic duct epithelial (HPDE) and pancreatic cancer (PaCa) cell lines. (A) CXCR4 mRNA levels in HPDE cells (H6c7) and PaCa cells (AsPC-1, BxPC-3, Capan2, MIA PaCa-2, PANC-1, and SW1990) measured by RT-qPCR. The mRNA level of CXCR4 was expressed relative to that of GAPDH in each sample. (B) CXCR4 protein levels in HPDE cells (H6c7) and PaCa cells (AsPC-1, BxPC-3, Capan2, MIA PaCa-2, PANC-1, and SW1990) measured by western blotting. (C) The calculated band density of CXCR4 on western blots relative to that of GAPDH in each sample. Comparisons between HPDE (H6c7) cells and PaCa cells were evaluated using t-tests. "P<0.05.

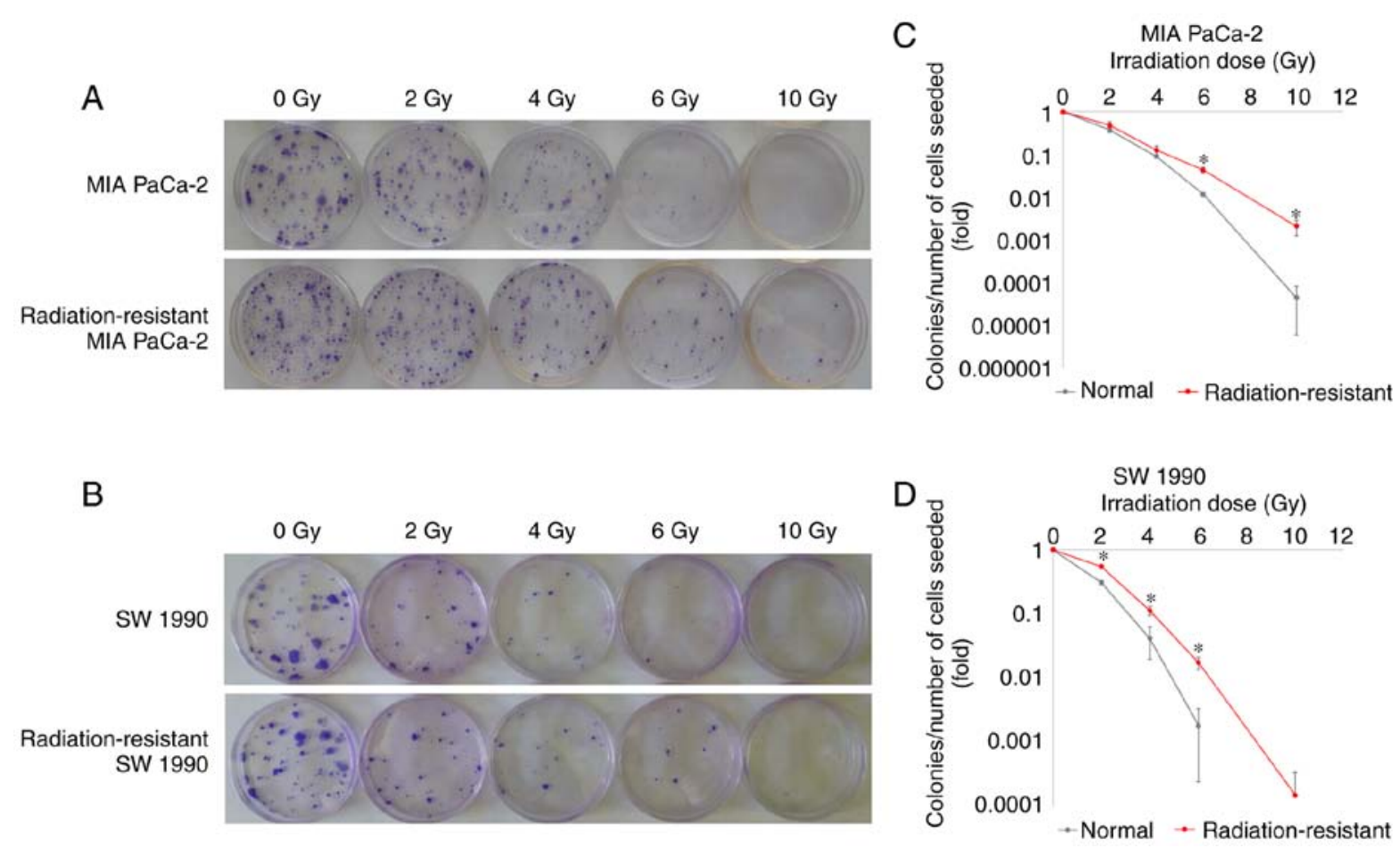

Figure 3. Effects of irradiation on the colonization of normal and radiation-resistant pancreatic cancer (PaCa) cell lines (MIA PaCa-2 and SW1990). The number of radiation-resistant PaCa cells to be seeded $(200,400,1,000,2,000$, or 40,000) in 60-mm dishes depended on the dose (0, 2, 4, 6, or 10 Gy). After culturing the cells overnight, irradiation was performed at doses of 0-10 Gy. (A and B) After culturing for another 14 days, the cells were fixed and stained, and the number of colonies formed was counted. The survival rate was calculated as the number of colonies divided by the number of seeded cells. (C) MIA $\mathrm{PaCa}-2$ and (D) SW1990 cells. Comparisons between normal PaCa cells and radiation-resistant PaCa cells were evaluated using t-tests. ${ }^{*} \mathrm{P}<0.05$.

(AMD), which has been reported to act as a CXCR4 antagonist. Similarly, coculture with FBs enhanced the invasion ability of PaCa cell lines, and this increase was suppressed by AMD070 (Fig. 5A-D).
Effects of irradiation and AMD070 on radiation-resistant $\mathrm{PaCa}$ cells. Irradiation (2 Gy) significantly suppressed the colonization of both normal and radiation-resistant MIA PaCa-2 cells $(\mathrm{P}<0.05)$. AMD070 treatment significantly 
Table I. cDNA microarray of cancer stem cell markers and chemokine receptor genes.

\begin{tabular}{|c|c|c|c|}
\hline Cancer stem cell gene name & Fold change & Chemokine receptor gene name & Fold change \\
\hline Upregulated & \multicolumn{3}{|c|}{ Upregulated } \\
\hline CXCR4 & 16.37 & CXCR4 & 16.37 \\
\hline CD44 & 2.97 & CCR10 & 2.28 \\
\hline CD24 & 1.67 & CXCR3 & 1.64 \\
\hline Nestin & 1.65 & CXCR1 & 1.29 \\
\hline BMI-1 & 1.48 & CXCR5 & 1.22 \\
\hline ESA & 1.29 & CCR1 & 1.15 \\
\hline EpCAM & 1.18 & CCR2 & 1.15 \\
\hline Downregulated & & CCR3 & 1.15 \\
\hline ALDH1A1 & 0.93 & CX3CR1 & 1.15 \\
\hline \multirow[t]{10}{*}{ PON1 } & 0.83 & CCR9 & 1.14 \\
\hline & & CXCR2 & 1.13 \\
\hline & & CXCR6 & 1.13 \\
\hline & & CCR8 & 1.13 \\
\hline & & CCR7 & 1.05 \\
\hline & \multicolumn{3}{|c|}{ Downregulated } \\
\hline & & CCR5 & 0.92 \\
\hline & & CCR4 & 0.86 \\
\hline & & XCR1 & 0.82 \\
\hline & & CCR6 & 0.80 \\
\hline
\end{tabular}

CXCR, C-X-C chemokine receptor; CD, cluster of differentiation; ESA epithelial-specific antigen; EpCAM, epithelial cell adhesion molecule; ALDH1A1, aldehyde dehydrogenase 1 family member A1; PON1, serum paraoxonase 1; BMI-1, B-cell-specific Moloney murine leukemia virus integration site 1; CCR, C-C chemokine receptor; XCR, XC chemokine receptor; $\mathrm{CX} 3 \mathrm{CR}, \mathrm{CX} 3 \mathrm{C}$ chemokine receptor.

suppressed the colonization of radiation-resistant MIA $\mathrm{PaCa}-2$ cells after irradiation ( $2 \mathrm{~Gy}$ ) compared with cells treated with irradiation alone $(\mathrm{P}<0.05$; Fig. $6 \mathrm{~A}$ and $\mathrm{B})$.

\section{Discussion}

The present study was designed to identify the factors contributing to radiation resistance in $\mathrm{PaCa}$ cells and to determine whether inhibition of these factors enhanced the therapeutic effect of radiation. Our findings confirmed that both $\mathrm{C}-\mathrm{X}-\mathrm{C}$ chemokine receptor type 4 (CXCR4) expression and invasion ability were enhanced in radiation-resistant $\mathrm{PaCa}$ cell lines compared with that in normal PaCa cell lines. Furthermore, the CXCR4 antagonist AMD070 suppressed the PaCa cell invasion enhanced by $\mathrm{C}-\mathrm{X}-\mathrm{C}$ motif chemokine ligand 12 (CXCL12) treatment or fibroblast (FB) coculture, and when used in combination with irradiation, AMD070 suppressed the colonization of radiation-resistant $\mathrm{PaCa}$ cells.

Overexpression of CXCR4 has been confirmed in a variety of tumors $(39,40)$. CXCL12, a ligand for CXCR4, is a chemokine secreted by stromal cells, FBs, and epithelial cells in a wide range of tissues (41). CXCL12/CXCR4 signaling affects all stages of tumor metastasis, including migration, proliferation, and angiogenesis (42-45). Notably, tumor growth is promoted by a small number of tumor stem cells in cancers (46). CXCR4 is a stem cell marker in $\mathrm{PaCa}$ (47) and is overexpressed in cancer tissues compared with that noted in normal pancreatic tissues; activation of the CXCL12/CXCR4 axis promotes the migration and invasion of $\mathrm{PaCa}$ cells $(30,42)$. Patients with high CXCR4 expression in their resected $\mathrm{PaCa}$ tissues exhibit poor survival (48). These findings are consistent with the results of the present study. Moreover, we observed differences in the expression levels of $C X C R 4$ mRNA and CXCR4 protein in $\mathrm{PaCa}$ cell lines. Thus, we believe that these differences resulted from alterations in the transcription process.

CXCL12/CXCR4 is involved in drug resistance in $\mathrm{PaCa}$ (49). We previously demonstrated an association between CXCL12/CXCR4 signaling and gemcitabine resistance in gemcitabine-resistant $\mathrm{PaCa}$ cell lines (32). In addition, CXCR4 may be involved in radiation resistance in colorectal cancer (50), thyroid cancer (51), and non-small cell lung cancer (52). We established radiation-resistant $\mathrm{PaCa}$ cell lines to investigate the factors involved in the radiation resistance of $\mathrm{PaCa}$. After performing DNA microarray analysis and finding that the expression of CXCR4 was higher in radiation-resistant than normal PaCa cell lines, we focused on CXCR4. This is the first report to investigate the importance of the CXCL12/CXCR4 signaling axis in radiation resistance and the effects of a CXCR4 antagonist on radiation-resistant $\mathrm{PaCa}$ cell lines.

$\mathrm{PaCa}$ manifests as a very stroma-rich, hard, and scirrhous mass, consisting mainly of FBs, immune cells, blood vessels, neurons, and various matricellular proteins (53). In $\mathrm{PaCa}$, cancer-associated FBs (CAFs) and myofibroblasts regulate local immunosuppression and promote tumor progression, invasion, and distant metastasis (54). CXCL12 is a chemokine that controls immunosuppression. Radiation-resistant $\mathrm{PaCa}$ cell lines with 

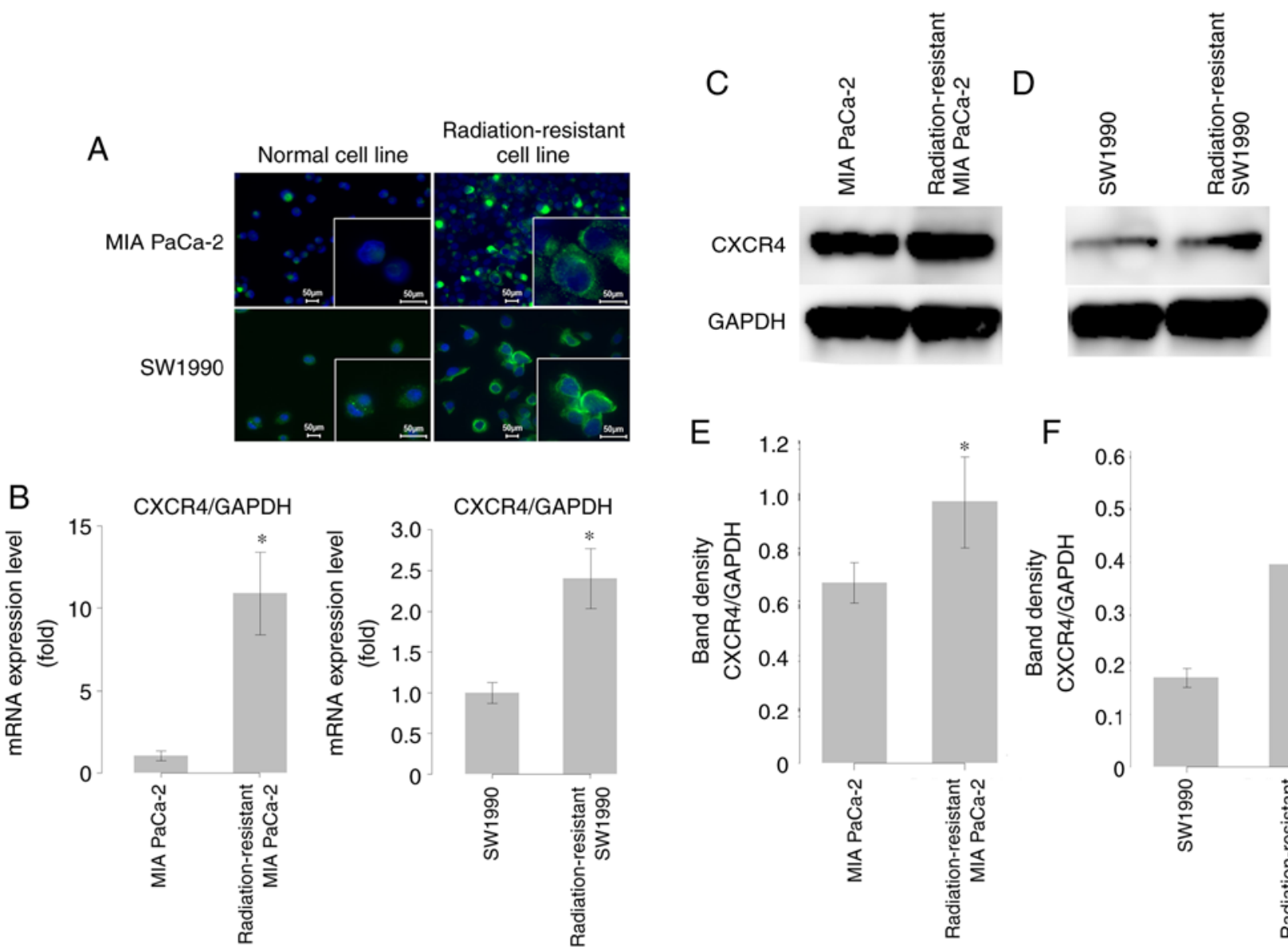

$\mathrm{F}$
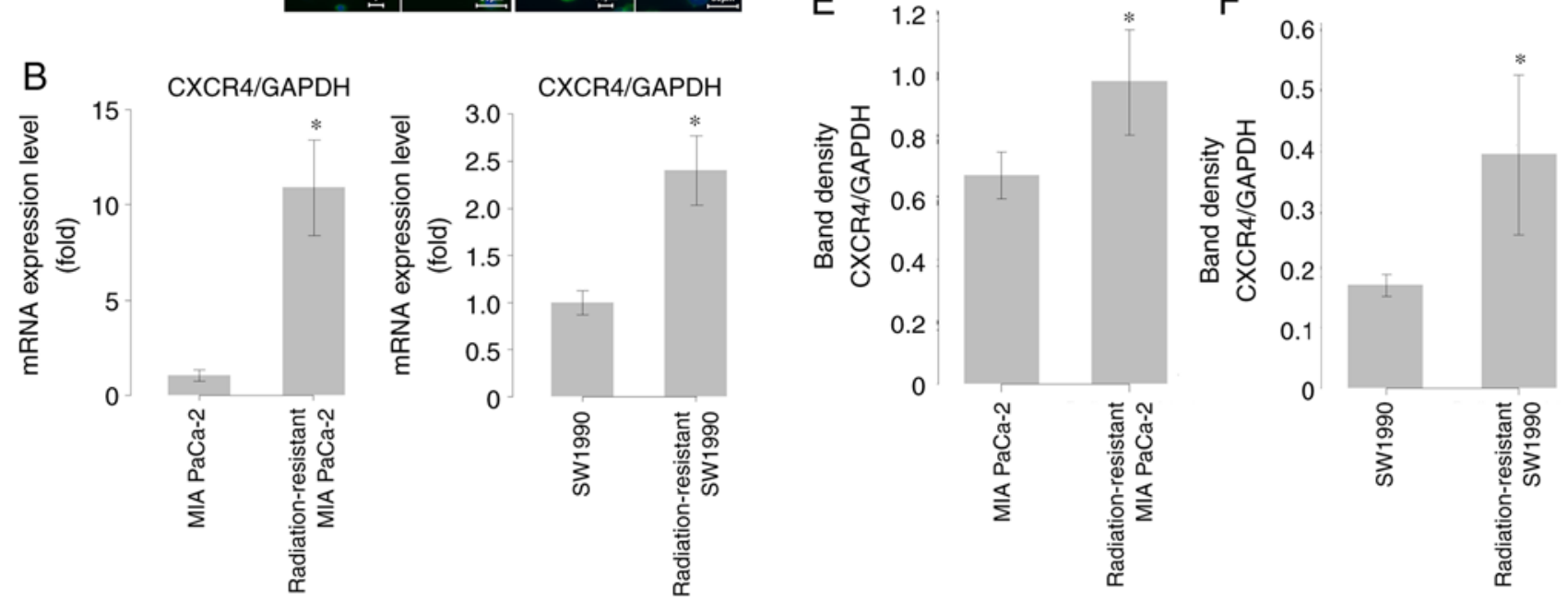

Figure 4. Comparison of C-X-C chemokine receptor type 4 (CXCR4) expression between normal and radiation-resistant pancreatic cancer (PaCa) cell lines. (A) CXCR4 protein expression in normal and radiation-resistant PaCa cell lines (MIA PaCa-2 and SW1990) detected by immunofluorescence staining. Green fluorescence represents CXCR4, and blue fluorescence represents DAPI. Magnification, x200. (B) CXCR4 mRNA levels in normal and radiation-resistant PaCa cell lines (MIA PaCa-2 and SW1990) measured by RT-qPCR. The mRNA level of CXCR4 was expressed relative to that of GAPDH in each sample. (C and D) CXCR4 protein levels in normal and radiation-resistant PaCa cell lines (MIA PaCa-2 and SW1990) measured by western blotting. (E and F) The calculated band density of CXCR4 on western blots relative to that of GAPDH in each sample. Comparisons between normal PaCa cells and radiation-resistant $\mathrm{PaCa}$ cells were evaluated using t-tests. ${ }^{*} \mathrm{P}<0.05$.

high expression of CXCR4 exhibited enhanced invasion ability compared with normal $\mathrm{PaCa}$ cell lines, and the invasion ability was further enhanced by the addition of CXCL12 or coculture with FBs. C-X-C chemokine receptor type 7 (CXCR7) is another receptor for CXCL12 and has also been reported to play important roles in cancer invasion (55). Therefore, we evaluated the mRNA levels of $C X C R 7$ in normal and radiation-resistant PaCa cell lines using RT-qPCR; however, our results showed that CXCR7 expression was not enhanced in radiation-resistant $\mathrm{PaCa}$ cell lines (data not shown). Furthermore, irradiation of pancreatic CAFs was found to enhance the secretion of CXCL12 from CAFs (56); therefore, the role of the CXCL12/CXCR4 axis in irradiation of $\mathrm{PaCa}$ is also noteworthy in terms of the relationship between $\mathrm{PaCa}$ and $\mathrm{FBs}$.

AMD070 is a small-molecule antagonist of CXCR4 that is orally bioavailable, selective, and reversible (24). In vitro, AMD070 inhibits the binding of CXCL12 to CXCR4 and blocks CXCL12-induced signaling (57). In a phase 2 trial, the therapeutic effects of AMD070 on warts, hypogammaglobulinemia, infections, and myelokathexis syndrome, a congenital immunodeficiency disease (58), were evaluated, and the results confirmed that AMD070 was generally safe, although some additional tests are required. We evaluated the toxicity of
AMD070 in PaCa cell lines and found that concentrations up to $20 \mu \mathrm{M}$ did not affect cell viability (data not shown). In both normal and radiation-resistant $\mathrm{PaCa}$ cell lines, the invasion ability enhanced by the addition of CXCL12 or coculture with FBs was suppressed by AMD070 treatment. However, the addition of AMD070 alone did not suppress parental cell invasion ability, probably due to the low concentration used or the short incubation time. Furthermore, the colonization of radiation-resistant $\mathrm{PaCa}$ cell lines was suppressed after treatment with AMD070, followed by irradiation. Irradiation alone had a sufficient effect on the colonization of normal $\mathrm{PaCa}$ cell lines, and the addition of AMD070 did not enhance the effect of irradiation. This result suggests that AMD070 treatment may enhance the therapeutic effects of irradiation in radiation-resistant $\mathrm{PaCa}$ and that the CXCL12/CXCR4 axis may be involved in radiation resistance.

The present study had some limitations. First, we did not perform experiments confirming the protein expression of the differentially expressed genes identified in the microarray analysis. Additionally, we did not perform experiments using CXCR4-overexpressing PaCa cell lines. In addition, we did not evaluate the mechanisms of CXCR4 in radiation-resistant $\mathrm{PaCa}$ cell lines in the absence of 

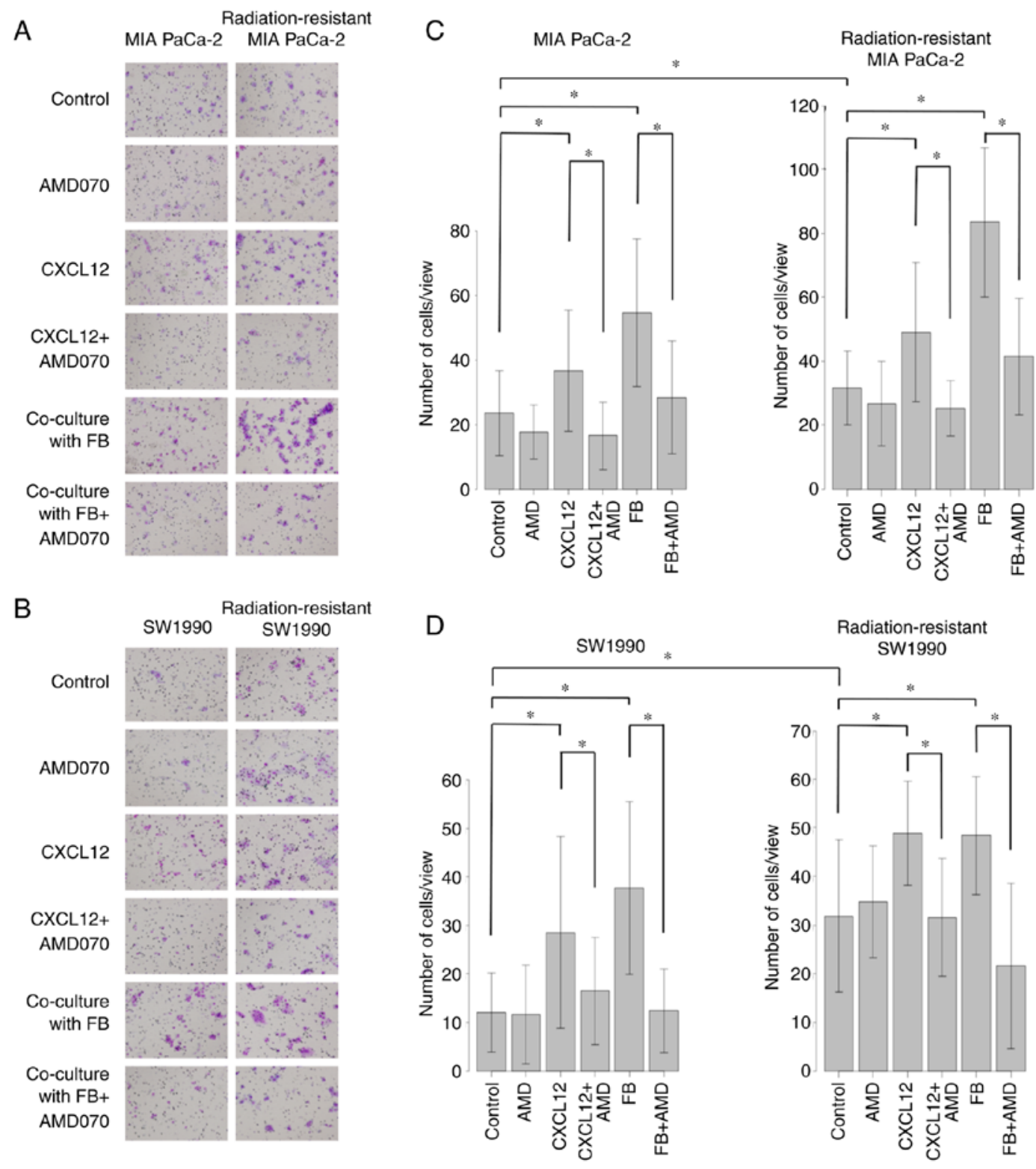

Figure 5. Altered invasiveness of pancreatic cancer (PaCa) cells after $\mathrm{C}-\mathrm{X}-\mathrm{C}$ motif chemokine ligand 12 (CXCL12) treatment or coculture with fibroblasts (FBs), in the absence or presence of a C-X-C chemokine receptor type 4 (CXCR4) antagonist (AMD070). The invasiveness of normal and radiation-resistant $\mathrm{PaCa}$ cell lines was assessed using the double chamber method using a Matrigel invasion assay system. PaCa cells $\left(1 \times 10^{5}\right)$ were seeded in Matrigel-precoated Transwell chambers and allowed to migrate for $24 \mathrm{~h}$. The effect of adding CXCL12 $(100 \mathrm{ng} / \mathrm{ml})$ to the culture medium or coculture with FBs, in the absence of presence of AMD070 $(1 \mu \mathrm{M})$ treatment, on PaCa cell invasion was also assessed. (A and B) The cells that invaded through the membrane to the bottom of the upper chamber after fixing and staining. Magnification x100. (C and D) The number of invading cells in nine random microscopic fields. Comparisons for each group were evaluated using two-way analysis of variance with post-hoc Bonferroni tests. ${ }^{*} \mathrm{P}<0.05$.
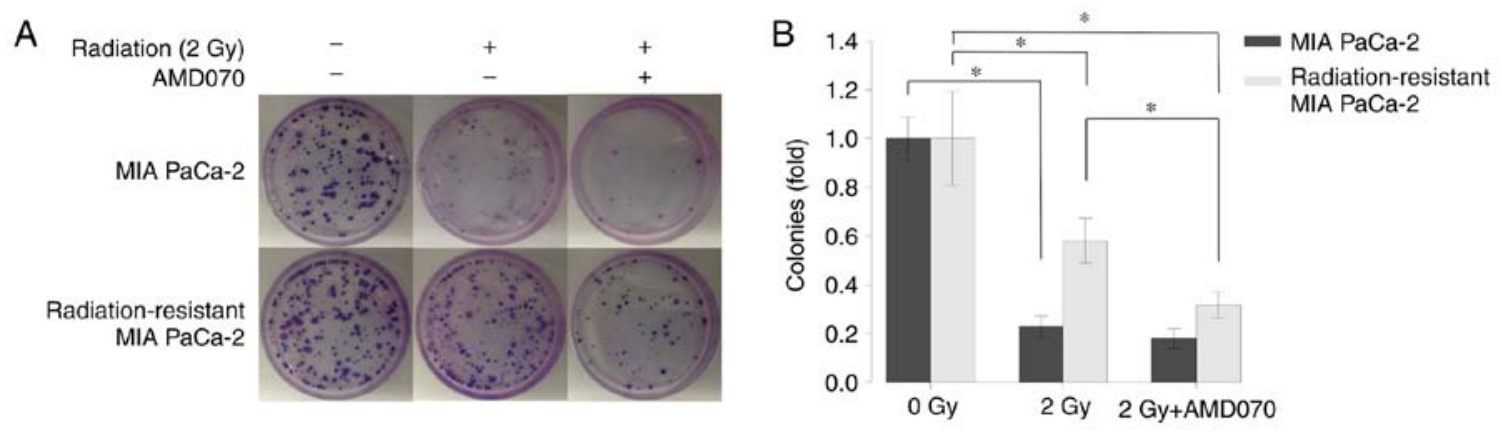

Figure 6. Effects of radiation and treatment with a C-X-C chemokine receptor type 4 (CXCR4) antagonist (AMD070) on the colonization of normal and radiation-resistant pancreatic cancer cells (MIA PaCa-2). Normal and radiation-resistant MIA PaCa-2 cells were treated with AMD070 ( $2.5 \mu \mathrm{M})$ for $72 \mathrm{~h}$, after which 200 cells were seeded in 6-cm dishes and irradiated at a dose of $2 \mathrm{~Gy}$. (A) The fixed and stained cells after 14 days of culture following irradiation. (B) The number of cell colonies. Comparisons among groups were evaluated using two-way analysis of variance with post-hoc Bonferroni tests. "P<0.05. 
CXCL12 because CXCL12 is always secreted by stromal cells, and further studies are still needed to elucidate the mechanisms of radiation resistance in cell derivatives in the absence of CXCL12.

In conclusion, the results of the present study showed that CXCL12/CXCR4 signaling enhanced the invasion ability of $\mathrm{PaCa}$ cell lines and that CXCL12/XCXR4 signaling was more active in radiation-resistant $\mathrm{PaCa}$ cell lines. We also showed that the CXCR4 antagonist AMD070 suppressed the invasion ability enhanced by CXCL12 treatment or FB coculture in radiation-resistant $\mathrm{PaCa}$ cell lines and promoted the effects of irradiation on radiation-resistant $\mathrm{PaCa}$ cell lines. Therefore, AMD070 may represent a more effective therapeutic agent for $\mathrm{PaCa}$, particularly when used in combination with irradiation. However, further investigations are required, including in vivo animal experiments with nude mice, before AMD070 can be used in the clinical setting.

\section{Acknowledgements}

Not applicable.

\section{Funding}

Not applicable.

\section{Availability of data and materials}

The data generated or analyzed in this study are included in the published article.

\section{Authors' contributions}

TK and YM contributed to the conception and design of the study, analyzed and interpreted the data, and wrote and reviewed the manuscript. TK, YM, KO, YH, HI, KS, MM, HT, and ST designed the study. TK, YM, GU, HM, and YA acquired the data. TK, YA, and YM confirmed the authenticity of all raw data. HM, KO, YH, MM, and RO wrote the Materials and methods section of the manuscript. YM, HT, $\mathrm{RO}$, and ST provided technical, administrative, or material support for performing RT-qPCR, western blotting, and invasion assays. YM supervised the study. All authors read the final manuscript and are equally responsible for all aspects of the study, ensuring its integrity and accuracy.

\section{Ethics approval and consent to participate}

This study was conducted with the approval of the institutional review board established by Nagoya City University (Nogoya, Japan) (approval no. 60-18-0025, date of approval; May 6, 2018).

\section{Patient consent for publication}

Not applicable.

\section{Competing interests}

The authors declare that they have no competing interests.

\section{References}

1. Siegel RL, Miller KD and Jemal A: Cancer statistics, 2020. CA Cancer J Clin 70: 7-30, 2020.

2. Conroy T, Desseigne F, Ychou M, Bouché O, Guimbaud R, Bécouarn Y, Adenis A, Raoul JL, Gourgou-Bourgade S, de la Fouchardière $\mathrm{C}$, et al: FOLFIRINOX versus gemcitabine for metastatic pancreatic cancer. N Engl J Med 364: 1817-1825, 2011.

3. Williet N, Petrillo A, Roth G, Ghidni M, Petrova M, Forestier J, Lopez A, Thoor A, Weislinger L, De Vita F, et al: Gemcitabine/nab-paclitaxel versus FOLFIRINOX in locally advanced pancreatic cancer: A European multicenter study. Cancers (Basel) 13: 2797, 2021.

4. de Geus SWL, Eskander MF, Kasumova GG, Ng SC, Kent TS, Mancias JD, Callery MP, Mahadevan A and Tseng JF: Stereotactic body radiotherapy for unresected pancreatic cancer: A nationwide review. Cancer 123: 4158-4167, 2017.

5. Krishnan S, Chadha AS, Suh Y, Chen HC, Rao A, Das P, Minsky BD, Mahmood U, Delclos ME, Sawakuchi GO, et al: Focal radiation therapy dose escalation improves overall survival in locally advanced pancreatic cancer patients receiving induction chemotherapy and consolidative chemoradiation. Int $\mathrm{J}$ Radiat Oncol Biol Phys 94: 755-765, 2016.

6. Shinoto M, Terashima K, Suefuji H, Matsunobu A, Toyama S, Fukunishi K and Shinoyama Y: A single institutional experience of combined carbon-ion radiotherapy and chemotherapy for unresectable locally advanced pancreatic cancer. Radiother Oncol 129: 333-339, 2018.

7. Matsuda T, Ajiki W, Marugame T, Ioka A, Tsukuma H, Sobue T and Research Group of Population-Based Cancer Registries of Japan: Population-based survival of cancer patients diagnosed between 1993 and 1999 in Japan: A chronological and international comparative study. Jpn J Clin Oncol 41: 40-51, 2011.

8. Rahib L, Smith BD, Aizenberg R, Rosenzweig AB, Fleshman JM and Matrisian LM: Projecting cancer incidence and deaths to 2030: the unexpected burden of thyroid, liver, and pancreas cancers in the United States. Cancer Res 74: 2913-2921, 2014

9. Bilimoria KY, Bentrem DJ, Ko CY, Stewart AK, Winchester DP and Talamonti MS: National failure to operate on early stage pancreatic cancer. Ann Surg 246: 173-180, 2007.

10. Doi R,Imamura M,Hosotani R,Imaizumi T,Hatori T, Takasaki K, Funakoshi A, Wakasugi H, Asano T, Hishinuma S, et al: Surgery versus radiochemotherapy for resectable locally invasive pancreatic cancer: final results of a randomized multi-institutional trial. Surg Today 38: 1021-1028, 2008.

11. Vincent A, Herman J, Schulick R, Hruban RH and Goggins M: Pancreatic cancer. Lancet 378: 607-620, 2011.

12. Sultana A, Tudur Smith C, Cunningham D, Starling N, Tait D, Neoptolemos JP and Ghaneh P: Systematic review, including meta-analyses, on the management of locally advanced pancreatic cancer using radiation/combined modality therapy. Br J Cancer 96: 1183-1190, 2007.

13. Vandercappellen J, Van Damme J and Struyf S: The role of CXC chemokines and their receptors in cancer. Cancer Lett 267: 226-244, 2008.

14. Kulbe H, Levinson NR, Balkwill F and Wilson JL: The chemokine network in cancer-much more than directing cell movement. Int J Dev Biol 48: 489-496, 2004.

15. Feng Y, Broder CC, Kennedy PE and Berger EA: Pillars article: HIV-1 entry cofactor: functional cDNA cloning of a seven-transmembrane, G protein-coupled receptor. Science. 1996. 272: 872-877. J Immunol 186: 6076-6081, 2011.

16. Balkwill F: The significance of cancer cell expression of the chemokine receptor CXCR4. Semin Cancer Biol 14: 171-179, 2004.

17. Chatterjee S, Behnam Azad B and Nimmagadda S: The intricate role of CXCR4 in cancer. Adv Cancer Res 124: 31-82, 2014.

18. Zlotnik A: New insights on the role of CXCR4 in cancer metastasis. J Pathol 215: 211-213, 2008.

19. Zhang J, Liu C, Mo X, Shi H and Li S: Mechanisms by which CXCR4/CXCL12 cause metastatic behavior in pancreatic cancer. Oncol Lett 15: 1771-1776, 2018.

20. Krieg A, Riemer JC, Telan LA, Gabbert HE and Knoefel WT: CXCR4-a prognostic and clinicopathological biomarker for pancreatic ductal adenocarcinoma: A meta-analysis. PLoS One 10: e0130192, 2015.

21. Cui K, Zhao W, Wang C, Wang A, Zhang B, Zhou W, Yu J, Sun Z and Li S: The CXCR4-CXCL12 pathway facilitates the progression of pancreatic cancer via induction of angiogenesis and lymphangiogenesis. J Surg Res 171: 143-150, 2011. 
22. Sleightholm RL, Neilsen BK, Li J, Steele MM, Singh RK, Hollingsworth MA and Oupicky D: Emerging roles of the CXCL12/CXCR4 axis in pancreatic cancer progression and therapy. Pharmacol Ther 179: 158-170, 2017.

23. De Clercq E: The bicyclam AMD3100 story. Nat Rev Drug Discov 2: 581-587, 2003.

24. Skerlj RT, Bridger GJ, Kaller A, McEachern EJ, Crawford JB, Zhou Y, Atsma B, Langille J, Nan S, Veale D, et al: Discovery of novel small molecule orally bioavailable $\mathrm{C}-\mathrm{X}-\mathrm{C}$ chemokine receptor 4 antagonists that are potent inhibitors of T-tropic (X4) HIV-1 replication. J Med Chem 53: 3376-3388, 2010.

25. Cabioglu N, Summy J, Miller C, Parikh NU, Sahin AA, Tuzlali S, Pumiglia K, Gallick GE and Price JE: CXCL-12/stromal cell-derived factor-1alpha transactivates HER2-neu in breast cancer cells by a novel pathway involving Src kinase activation. Cancer Res 65: 6493-6497, 2005.

26. Hartmann TN, Burger JA, Glodek A, Fujii N and Burger M: CXCR4 chemokine receptor and integrin signaling co-operate in mediating adhesion and chemoresistance in small cell lung cancer (SCLC) cells. Oncogene 24: 4462-4471, 2005.

27. Ohira S, Sasaki M, Harada K, Sato Y, Zen Y, Isse K, Kozaka K, Ishikawa A, Oda K, Nimura Y and Nakanuma Y: Possible regulation of migration of intrahepatic cholangiocarcinoma cells by interaction of CXCR4 expressed in carcinoma cells with tumor necrosis factor-alpha and stromal-derived factor-1 released in stroma. Am J Pathol 168: 1155-1168, 2006.

28. Yasumoto K, Koizumi K, Kawashima A, Saitoh Y, Arita Y, Shinohara K, Minami T, Nakayama T, Sakurai H, Takahashi Y, et al: Role of the CXCL12/CXCR4 axis in peritoneal carcinomatosis of gastric cancer. Cancer Res 66: 2181-2187, 2006.

29. Marchesi F, Monti P, Leone BE, Zerbi A, Vecchi A, Piemonti L, Mantovani A and Allavena P: Increased survival, proliferation, and migration in metastatic human pancreatic tumor cells expressing functional CXCR4. Cancer Res 64: 8420-8427, 2004

30. Saur D, Seidler B, Schneider G, Algül H, Beck R, SenekowitschSchmidtke R, Schwaiger M and Schmid RM: CXCR4 expression increases liver and lung metastasis in a mouse model of pancreatic cancer. Gastroenterology 129: 1237-1250, 2005.

31. Bockorny B, Semenisty V, Macarulla T, Borazanci E, Wolpin BM Stemmer SM, Golan T, Geva R, Borad MJ, Pedersen KS, et al: BL-8040, a CXCR4 antagonist, in combination with pembrolizumab and chemotherapy for pancreatic cancer: the COMBAT trial. Nat Med 26: 878-885, 2020

32. Morimoto M, Matsuo Y, Koide S, Tsuboi K, Shamoto T, Sato T, Saito K, Takahashi $\mathrm{H}$ and Takeyama H: Enhancement of the CXCL12/CXCR4 axis due to acquisition of gemcitabine resistance in pancreatic cancer: Effect of CXCR4 antagonists. BMC Cancer 16: 305, 2016

33. Chang JT, Chan SH, Lin CY, Lin TY, Wang HM, Liao CT, Wang TH, Lee LY and Cheng AJ: Differentially expressed genes in radioresistant nasopharyngeal cancer cells: gp96 and GDF15. Mol Cancer Ther 6: 2271-2279, 2007.

34. Matsuyama A, Inoue H, Shibuta K, Tanaka Y, Barnard GF, Sugimachi K and Mori M: Hepatoma-derived growth factor is associated with reduced sensitivity to irradiation in esophageal cancer. Cancer Res 61: 5714-5717, 2001.

35. Fukuda K, Sakakura C, Miyagawa K, Kuriu Y, Kin S, Nakase Y Hagiwara A, Mitsufuji S, Okazaki Y, Hayashizaki Y and Yamagishi H: Differential gene expression profiles of radioresistant oesophageal cancer cell lines established by continuous fractionated irradiation. Br J Cancer 91: 1543-1550, 2004

36. Wang T, Tamae D, LeBon T, Shively JE, Yen Y and Li JJ: The role of peroxiredoxin II in radiation-resistant MCF-7 breast cancer cells. Cancer Res 65: 10338-10346, 2005.

37. Xu QY, Gao Y, Liu Y, Yang WZ and Xu XY: Identification of differential gene expression profiles of radioresistant lung cancer cell line established by fractionated ionizing radiation in vitro. Chin Med J (Engl) 121: 1830-1837, 2008

38. Bustin SA: Quantification of mRNA using real-time reverse transcription PCR (RT-PCR): Trends and problems. J Mo Endocrinol 29: 23-39, 2002.

39. Sasaki K, Natsugoe $S$, Ishigami $S$, Matsumoto $M$, Okumura $H$, Setoyama T, Uchikado Y, Kita Y, Tamotsu K, Sakurai T, et al: Expression of CXCL12 and its receptor CXCR4 correlates with lymph node metastasis in submucosal esophageal cancer. J Surg Oncol 97: 433-438, 2008

40. Taichman RS, Cooper C, Keller ET, Pienta KJ, Taichman NS and McCauley LK: Use of the stromal cell-derived factor-1/CXCR4 pathway in prostate cancer metastasis to bone. Cancer Res 62: $1832-1837,2002$
41. Luther SA, Bidgol A, Hargreaves DC, Schmidt A, Xu Y, Paniyadi J, Matloubian M and Cyster JG: Differing activities of homeostatic chemokines CCL19, CCL21, and CXCL12 in lymphocyte and dendritic cell recruitment and lymphoid neogenesis. J Immunol 169: 424-433, 2002.

42. Billadeau DD, Chatterjee S, Bramati P, Sreekumar R, Shah V, Hedin K and Urrutia R: Characterization of the CXCR4 signaling in pancreatic cancer cells. Int J Gastrointest Cancer 37: 110-119, 2006

43. Zlotnik A: Chemokines in neoplastic progression. Semin Cancer Biol 14: 181-185, 2004.

44. Kucia M, Jankowski K, Reca R, Wysoczynski M, Bandura L, Allendorf DJ, Zhang J, Ratajczak J and Ratajczak MZ: CXCR4-SDF-1 signalling, locomotion, chemotaxis and adhesion. J Mol Histol 35: 233-245, 2004.

45. Müller A, Homey B, Soto H, Ge N, Catron D, Buchanan ME, McClanahan T, Murphy E, Yuan W, Wagner SN, et al: Involvement of chemokine receptors in breast cancer metastasis. Nature 410: 50-56, 2001

46. Batlle E and Clevers H: Cancer stem cells revisited. Nat Med 23: 1124-1134, 2017

47. Vaz AP, Ponnusamy MP, Seshacharyulu P and Batra SK: A concise review on the current understanding of pancreatic cancer stem cells. J Cancer Stem Cell Res 2: e1004, 2014.

48. Maréchal R, Demetter P, Nagy N, Berton A, Decaestecker C, Polus M, Closset J, Devière J, Salmon I and Van Laethem JL: High expression of CXCR4 may predict poor survival in resected pancreatic adenocarcinoma. $\mathrm{Br}$ J Cancer 100: 1444-1451, 2009.

49. Singh S, Srivastava SK, Bhardwaj A, Owen LB and Singh AP: CXCL12-CXCR4 signalling axis confers gemcitabine resistance to pancreatic cancer cells: a novel target for therapy. Br J Cancer 103: 1671-1679, 2010.

50. Wang D, Jiao C, Zhu Y, Liang D, Zao M, Meng X, Gao J, He Y, Liu W, Zhong Z and Cheng Z: Activation of CXCL12/CXCR4 renders colorectal cancer cells less sensitive to radiotherapy via up-regulating the expression of survivin. Exp Biol Med (Maywood) 242: 429-435, 2017.

51. Oweida A, Phan A, Vancourt B, Robin T, Hararah MK, Bhatia S, Milner D, Lennon S, Pike L, Raben D, et al: Hypofractionated radiotherapy is superior to conventional fractionation in an orthotopic model of anaplastic thyroid cancer. Thyroid 28: 739-747, 2018.

52. Kim JY, Kim HJ, Jung CW, Lee TS, Kim EH and Park MJ: CXCR4 uses STAT3-mediated slug expression to maintain radioresistance of non-small cell lung cancer cells: Emerges as a potential prognostic biomarker for lung cancer. Cell Death Dis 12: 48, 2021 .

53. Mahadevan D and Von Hoff DD: Tumor-stroma interactions in pancreatic ductal adenocarcinoma. Mol Cancer Ther 6: 1186-1197, 2007.

54. Neesse A, Algül H, Tuveson DA and Gress TM: Stromal biology and therapy in pancreatic cancer: A changing paradigm. Gut 64: 1476-1484, 2015.

55. Santagata $S$, Ieranò $C$, Trotta AM, Capiluongo A, Auletta F, Guardascione G and Scala S: CXCR4 and CXCR7 signaling pathways: A focus on the cross-talk between cancer cells and tumor microenvironment. Front Oncol 11: 591386, 2021.

56. Li D, Qu C, Ning Z, Wang H, Zang K, Zhuang L, Chen L, Wang P and Meng Z: Radiation promotes epithelial-to-mesenchymal transition and invasion of pancreatic cancer cell by activating carcinoma-associated fibroblasts. Am J Cancer Res 6: 2192-2206, 2016.

57. Mosi RM, Anastassova V, Cox J, Darkes MC, Idzan SR, Labrecque J, Lau G, Nelson KL, Patel K, Santucci Z, et al: The molecular pharmacology of AMD11070: An orally bioavailable CXCR4 HIV entry inhibitor. Biochem Pharmacol 83: 472-479, 2012.

58. Dale DC, Firkin F, Bolyard AA, Kelley M, Makaryan V, Gorelick K, Ebrahim T, Garg V, Tang W, Jiang H, et al: Results of a phase 2 trial of an oral CXCR4 antagonist, mavorixafor, for treatment of WHIM syndrome. Blood 136: 2994-3003, 2020 .

This work is licensed under a Creative Commons Attribution-NonCommercial-NoDerivatives 4.0 International (CC BY-NC-ND 4.0) License. 